\section{Colonial Service: Recent Appointments}

THE following appointments have recently been made in the Colonial Service: J. Bowden (entomologist, Gold Coast), senior specialist, Department of Agriculture, Gold Coast; T. W. Brandon (government chemist, Public Works Department, Gold Coast), specialist, water examination, Public Works Department, Gold Coast ; N. O. Walsh (senior scientific officer, Jamaica), deputy government chemist, Jamaica; H. M. Maugham-Brown (assistant conservator of forests, Tanganyika), conservator of forests, Tanganyika; T. P. Lecky (senior livestock officer, Jamaica), chief livestock officer, Jamaica; C. S. Ramage (scientific officer, Royal Observatory, Hong Kong), assistant director, Royal Observatory, Hong Kong; R. H. Bennison and B. F. Hanger, agricultural officers, Kenya; B. Buckler, agricultural officer, Zanzibar ; D. L. Curtis, plant breeder, Nigeria; J. W. Deøring, agricultural officer, Fiji ; G. Dowson, agricultural officer, Sarawak; M. J. Furber and A. B. Hearn, agricultural officers, Nyasaland ; R. C. Knill, agricultural officer, Sierra Leone; W. P. Mowat, plant pathologist, Tanganyika; A. J. Pritchard, botanist, Uganda; J. J. Rae, agricultural officer, Nigeria ; E. M. Laing, field geologist, Sierra Leone; G. P. Jones, geologist, Nigeria; A. R. Newton, geologist, Northern Rhodesia; W. J. Phillips, goologist, Uganda ; R. D. Brown, veterinary research officer (virologist), East Africa High Commission; T. E. Fletcher, scientific officer (chemist), East African Malaria Unit ; M. C. Williams, medical research officer, grade 3, East Africa High Commission; J. Williamson, research parasitologist, West African Institute for Trypanosomiasis Research, Nigeria; J. R. Lang-Brown, assistant conservator of forests, Uganda; M. J. Davies, assistant conservator of forests, Nigeria; S. R. M. Harvey, geologist, Fiji ; Miss E. M. Holden, biochemist, West African Cacao Research Institute, Gold Coast ; J. E. McKerlie, assistant conservator of forests, Tanganyika ; E. B. May, agronomist, West African Institute for Oil Palm Research, Nigeria; J. C. Parkinson, assistant conservator of forests, Fiji.

\section{The Night Sky in November}

FULL moon occurs on Nov. 10d. 14h. 29m., U.T., and new moon on Nov. $25 \mathrm{~d} .12 \mathrm{~h}$. $30 \mathrm{~m}$. The following conjunctions with the moon take place: Nov. 3d. 19h., Mars $5^{\circ}$ S.; Nov. 15d. 14h., Jupiter $2^{\circ}$ N.; Nov. 24d. 03h., Saturn $6^{\circ}$ N.; Nov. 24d. 03h., Mercury $6^{\circ}$ N.; Nov. 24d. 07h., Venus $2^{\circ}$ N. In addition to these conjunctions with the moon, Mercury is in conjunction with Saturn on Nov. 24d. $01 \mathrm{~h}$., Mercury $0.4^{\circ} \mathrm{S}$., and also in conjunction with Venus on Nov. 25d. 05h., Mercury $3^{\circ}$ N. ; and Venus is in conjunction with Saturn on Nov. 29d. 00h., Venus $2.5^{\circ} \mathrm{S}$. Mercury is a morning star and rises nearly two hours before the sun on November 15, when it is visible, but throughout most of the month it is too close to the sun for observation. Venus is unfavourably placed for observation during most of the month and is in inferior conjunction on November 15. At the end of the month it rises about two hours before the sun and can be seen in the eastern sky, stellar magnitude -4 . Mars, an evening star, sets at about $22 \mathrm{~h} .10 \mathrm{~m}$. during the month. Its stellar magnitude varies between $0 \cdot 1$ and 0.5 , the decrease in brightness being due to its increasing distance from the earth-from 91 to 111 million miles. It moves from Capricornus into Aquarius, and on
November 10 it lies almost south of and close to $\theta$ Capricorni. Jupiter rises at $21 \mathrm{~h}$. 35m., 20h. $45 \mathrm{~m}$. and $19 \mathrm{~h} .40 \mathrm{~m}$. on November 1,15 and 30 , respectively; owing to its decrease in distance from the earth by about 38 million miles, its stellar magnitude changes from -1.8 to -2 during the month. Saturn, in conjunction with the sun on November 5, is unobservable in the early part of the month; on November 15 it rises less than an hour before the sun but by the end of the month it rises at $5 \mathrm{~h} .30 \mathrm{~m}$., more than two hours before sunrise, and can be seen a little north-east of $\alpha$ Librae. Occultations of stars brighter than magnitude 6 are as follows, observations being made at Greenwich: Nov. 5d. 23h. $55 \cdot 7 \mathrm{~m} ., x$ Aquar. $(D)$; Nov. 6d. $22 \mathrm{~h} .27 \cdot 7 \mathrm{~m} ., x$ Pisc. $(D)$; Nov. 12d. $23 \mathrm{~h} .38 \cdot 6 \mathrm{~m} ., 121$ Taur. $(R)$; Nov. 14d. 05h. $52 \cdot 3 \mathrm{~m} ., d$ Gemi. $(R)$; Nov. $20 \mathrm{~d}$. 03h. $45.9 \mathrm{~m}$., $13 B$ Virg. $(R)$. $(D)$ and $(R)$ refer to disappearance and reappearance, respectively. The Andromedid meteors, associated with Biela's Comet, attain their maximum about November 28.

\section{Announcements}

Dr. D. A. Alluan, director of the Royal Scottish Museum, Edinburgh, has been elected president of the Royal Scottish Geographical Society.

THE title of reader in computational methods in the University of London has been conferred on Dr. A. D. Booth, in respect of his post at Birkbeck College.

As part of the United States conditional aid programme, the Ministry of Agriculture of Northern Ireland has awarded three postgraduate scholarships, each $£ 600$ a year, for a period up to two years, as follows : two scholarships in agricultural economics (farm management) to G. L. Morrison (University of Reading) and W. Thompson (University of Leeds); one scholarship in agricultural statistics to A. A. Rutherford (University of Aberdeen).

THe Fulmer Research Institute, Stoke Poges, Bucks, is arranging an open day, which will be held on November 2.

THE work of the London Group Laboratories of the British Iron and Steel Research Association will be open for inspection at 140 Battersea Park Road, London, S.W.11, on November 18 and 19.

IN conjunction with the annual congress of the British Institute of Radiology, an exhibition of X-ray apparatus will be held at the Royal Horticultural Hall, Vincent Square, Westminster, London, S.W.1, during November 23-26 (Nov. 23, 2 p.m.6 p.m.; Nov. 24 and 26,9 a.m. -6 p.m.; Nov. 25, 9 a.m. -8 p.m.). Admission tickets, which are free, can be obtained from the British Institute of Radiology, 32 Welbeck Street, London, W.1.

THe Northern Branch of Aslib will hold a one-day conference on November 19 in the North of England Mining and Mechanical Institute, Neville Hall, Newcastle upon Tyne, with Mr. R. W. Mann, managing director of Victor Products, Ltd., Wallsend upon Tyne, in the chair. Four papers will be read dealing respectively with the activities of Aslib; public technical library service for industry; microfilming; and new ideas and the small firm. The conference will be open to non-members on completion of a registration form (to be returned by November 12) which is obtainable from the honorary organizing secretary, Mr. E. Westerby, 11 Duchess Street, Whitley Bay, Northumberland. 